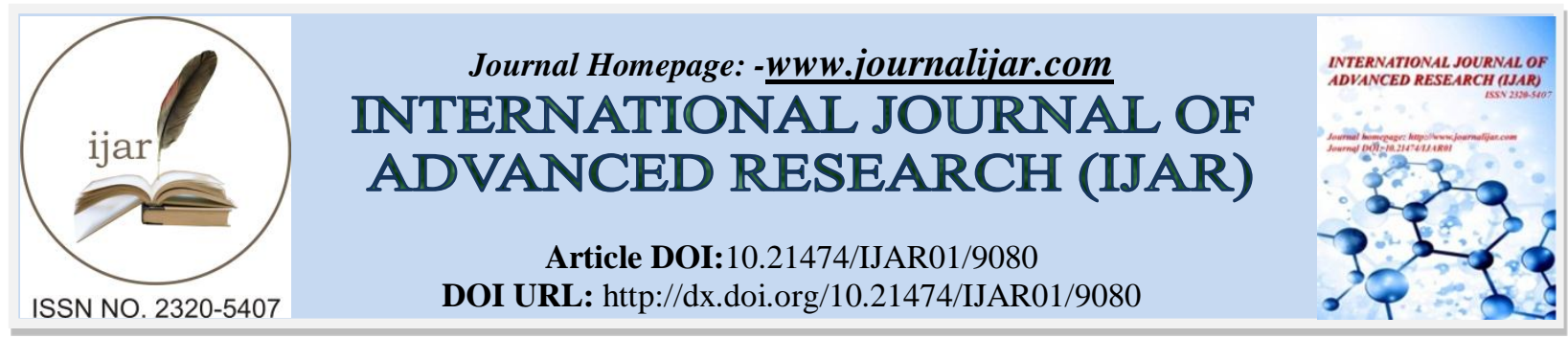

RESEARCH ARTICLE

\title{
RISK FACTORS FOR THE INCIDENCE OF TUBERCULOSIS IN CHILDREN AT SUMEDANG DISTRICT, WEST JAVA, INDONESIA.
}

\section{Ujang Nurjaman $^{1}$, Onny Setiani ${ }^{2}$ and Sulistiyani ${ }^{2}$.}

1. Students in the Environmental Health Master's Program at the Faculty of Public Health, Diponegoro University.

2. Teaching Staff for Environmental Health Master's Program at the Faculty of Public Health, Diponegoro University.

\section{Manuscript Info}

•.....................

Manuscript History

Received: 15 March 2019

Final Accepted: 17 April 2019

Published: May 2019

Key words:-

Oral submucous fibrosis, , Buccal Fat

Pad, Oropharyngeal, esophageal mucosa.

\section{Abstract}

Indonesia is ranked 3rd out of 8 countries with a high burden of Tuberculosis in the world. West Java Province became the first place in Indonesia with the number of new cases of Tuberculosis in children with $14.96 \%$ of the total Tuberculosis sufferers in West Java. The proportion of Tuberculosis in children cases at Sumedang District in 2018 amounted to 214 cases $(12.7 \%)$ of the total Tuberculosis cases (1693 cases). Tuberculosis in children should be a priority as in overcoming it, because children are the future of the nation that must be healthy, grow and develop optimally. Research about the risk factors for the incidence of Tuberculosis in children at Sumedang District has never been conducted. Identification of risk factors will be very useful for planning an appropriate Tuberculosis prevention interventions in Sumedang District. The purpose of this study was to analyze the characteristics and risk factors for the incidence of Tuberculosis in children at Sumedang District. The research method used was analytic observational with a case control study design with 45 cases and 45 controls. The results of bivariate analysis by implementing Chi Square test showed that the variables related were; ventilation area $(\mathrm{p}=0.011$, $\mathrm{OR}=3.4)$ home lighting $(\mathrm{p}=0.020, \mathrm{OR}=3.0)$, cigarette exposure $(\mathrm{p}=$ 0.042 , OR $=4,5)$, contact history $(\mathrm{p}=0,000 \mathrm{OR}=8,6)$, maternal behavior ( $\mathrm{p}=0,029, \mathrm{OR}=3.0)$ with the results of multivariate analysis by implementing logistic regression test showing the contact history $(\mathrm{p}$ $=0,000, \mathrm{OR}=12,0)$ and ventilation area $(\mathrm{p}=0,003$, OR $=5,4)$. Conclusion: Ventilation area, home lighting, cigarette exposure, contact history and maternal behavior were the risk factors for the incidence of Tuberculosis in children at Sumedang District with the dominant factor are contact history and ventilation area.

Copy Right, IJAR, 2019,. All rights reserved.

\section{Introduction:-}

Tuberculosis (TB) is a global health problem that becomes a priority to overcoming it in various countries and one of the goals in the SDGs (Sustainable Development Goals). ${ }^{1}$ Tuberculosis is one of the ten highest causes of death

Corresponding Author:-Ujang Nurjaman.

Address:-Students in the Environmental Health Master's Program at the Faculty of Public Health, 
worldwide. Based on WHO's data, on 2017 the new cases of Tuberculosis are most prevalent in the Southeast Asia region and the Western Pacific region with $62 \%$ of new cases, followed by African regions with $25 \%$ of new cases and $95 \%$ of their morbidity and mortality that is occurring in the developing countries. ${ }^{2}$ The eight highest contributors to new Tuberculosis cases in the world are India, China, Indonesia, Philippines, Pakistan, Nigeria, Bangladesh, and South Africa. Tuberculosis can affect all age of groups including children (age 0-14 years). Globally, in 2017 it was estimated that 1 million children were ill because of Tuberculosis and 230,000 children died from it. The estimated incidence of Tuberculosis in children covers $10 \%$ of all Tuberculosis events. ${ }^{2}$ A child who suffers from a chronic disease such as Tuberculosis will experience obstacles in his growth and development. ${ }^{3}$ Now the population of children aged $<15$ years is $26 \%$ of the total population in the world whose children should be healthy, grow and develop optimally. ${ }^{3,4}$ The proportion of Tuberculosis in children in Indonesia of the last 4 years continues to increase (2013-2017). there are 7, 1\%; 8.6\%; 9.0\%; and 10.1\% of the total Tuberculosis patients. ${ }^{4}$ As for those who ranked first in the new cases of Tuberculosis in children on 2017 were West Java province with a prevalence of 97 per 100,000 population of children. If the proportion is calculated, the Tuberculosis in children in West Java Province is $14.96 \%$ of the total Tuberculosis patients. ${ }^{4}$ Tuberculosis in children is a disease caused by infection from the bacteria called Mycobacterium tuberculosis and is contagious which attacks children (0-14 years). ${ }^{5}$ Transmission of Tuberculosis in children is through the air with the general source of transmission is adult Tuberculosis patients with Acid-Fast Bacillus (AFB) (+). The national Tuberculosis program seems to focus more on adult patients as a result of Tuberculosis in children that has not received adequate attention. ${ }^{6,7}$ Even though it is no less important considering that children are the generation of the nation that needs healthy and optimal growth and development. Based on the above phenomenon, Tuberculosis in children is an increasingly important and an urgent public health challenge for attention. Identification of risk factors are very useful for planning appropriate Tuberculosis prevention of interventions.

\section{Material And Methods:-}

Study Design is observational analitic case control study. The case population is children who aged 0-14 years, living in Sumedang Regency who were diagnosed with Tuberculosis in 2018 which was recorded in the Integrated Tuberculosis Information System (ITIS) in the public health center in Sumedang Regency. Meanwhile the control population are children aged 0-14 years who are living in Sumedang Regency who were recorded as have been receiving treatment in 2018 at the public health center in Sumedang Regency with a diagnosis of have no Tuberculosis or other lung disease. Sample size are 45 cases and 45 controls calculated by Lameshow formula and sample technique is purposive sampling. ${ }^{8,9}$ Inclusion case criteria are age 0-14 years, female and Male, recorded in medical records / SITT 2018 with diagnosis of Tuberculosis in children, no history of Tuberculosis treatment, and domiciled in Sumedang Regency. Exclusion case/control criteria are when visited, respondents had moved out to a new residence, parents of respondents were not willing to be interviewed / observed, and there was a change in the condition of the house during the illness until the interview. Statistical analysis in this study was carried out by implementing univariate analysis, bivariate analysis and multivariate analysis.

\section{Result:-}

Location study in this research is in health center working area in Sumedang District includes Jatinangor Health Center, Margajaya Health Center, South Sumedang Health Center and Situ Health Center. The results of this study were analyzed by univariate, bivariate and multivariate. In this table bellow shows size samples in each health center:

Table 1:-Sample Distribution For This Reseach According to 4 Working Area Health Center at Sumedang District

\begin{tabular}{|l|c|c|c|c|c|c|}
\hline \multirow{2}{*}{ Health Center } & \multicolumn{2}{|c|}{ Cases } & \multicolumn{2}{c|}{ Control } & \multirow{2}{*}{ Total } & \\
\cline { 2 - 7 } & $\mathrm{N}$ & $\%$ & $\mathrm{~N}$ & $\%$ & & 22 \\
\hline Jatinangor & 11 & 24,4 & 11 & 24,4 & 24,4 \\
\hline Margajaya & 10 & 22,2 & 10 & 22,2 & 20 & 22,2 \\
\hline Sumedang Selatan & 11 & 24,4 & 11 & 24,4 & 22 & 24,4 \\
\hline Situ & 13 & 29 & 13 & 29 & 26 & 29 \\
\hline Total & 45 & 100 & 45 & 100 & 90 & 100 \\
\hline
\end{tabular}

Table 2:-Univariate Analysis Result

\begin{tabular}{|c|c|c|c|c|}
\hline \multirow[t]{2}{*}{ Characteristics } & \multicolumn{2}{|c|}{ Cases } & \multicolumn{2}{|c|}{ Control } \\
\hline & $\mathrm{n}(45)$ & $\%$ & $\mathrm{n}(45)$ & $\%$ \\
\hline Age & & & & \\
\hline
\end{tabular}




\begin{tabular}{|c|c|c|c|c|}
\hline $\begin{array}{l}<5 \text { years } \\
\geq 5 \text { years }\end{array}$ & $\begin{array}{l}15 \\
30 \\
\end{array}$ & $\begin{array}{l}33,3 \\
66,7 \\
\end{array}$ & $\begin{array}{l}21 \\
24 \\
\end{array}$ & $\begin{array}{l}46,7 \\
53,3 \\
\end{array}$ \\
\hline $\begin{array}{l}\text { Gender } \\
\text { Male } \\
\text { Female } \\
\end{array}$ & $\begin{array}{l}35 \\
10 \\
\end{array}$ & $\begin{array}{l}77,8 \\
22,2 \\
\end{array}$ & $\begin{array}{l}27 \\
18 \\
\end{array}$ & $\begin{array}{l}60 \\
40 \\
\end{array}$ \\
\hline $\begin{array}{l}\text { Mother's education } \\
\text { Low } \\
\text { High }\end{array}$ & $\begin{array}{l}20 \\
25 \\
\end{array}$ & $\begin{array}{l}44,4 \\
55,6 \\
\end{array}$ & $\begin{array}{l}23 \\
22 \\
\end{array}$ & $\begin{array}{l}51,1 \\
48,9 \\
\end{array}$ \\
\hline $\begin{array}{l}\text { Occupancy density } \\
<9 \mathrm{~m}^{2} \text { per person } \\
\geq 9 \mathrm{~m}^{2} \text { per person } \\
\end{array}$ & $\begin{array}{l}19 \\
26 \\
\end{array}$ & $\begin{array}{l}42,2 \\
57,8 \\
\end{array}$ & $\begin{array}{l}15 \\
30\end{array}$ & $\begin{array}{l}33,3 \\
66,7\end{array}$ \\
\hline $\begin{array}{l}\text { Extensive ventilation } \\
<10 \% \text { from the floor area } \\
\geq 10 \% \text { from the floor area }\end{array}$ & $\begin{array}{l}32 \\
13 \\
\end{array}$ & $\begin{array}{l}71,1 \\
28,9 \\
\end{array}$ & $\begin{array}{l}19 \\
26 \\
\end{array}$ & $\begin{array}{l}42,2 \\
57,8 \\
\end{array}$ \\
\hline $\begin{array}{l}\text { House Temperature } \\
\text { Mycobaterium TB Temperature }\left(25-40 \mathrm{C}^{\mathrm{o}}\right) \\
\text { Non Mycobacterium TB Temperature } \\
\left(<25 \mathrm{C}^{\mathrm{o}} \text { dan }>40 \mathrm{C}^{\circ}\right)\end{array}$ & $\begin{array}{l}33 \\
12\end{array}$ & $\begin{array}{l}73,3 \\
26,7\end{array}$ & $\begin{array}{l}31 \\
14\end{array}$ & $\begin{array}{l}68,9 \\
13,3\end{array}$ \\
\hline $\begin{array}{l}\text { House Humidity Level } \\
<40 \% \text { and }>70 \% \\
40 \%-70 \%\end{array}$ & $\begin{array}{c}41 \\
4\end{array}$ & $\begin{array}{c}91.1 \\
8,9\end{array}$ & $\begin{array}{c}37 \\
8\end{array}$ & $\begin{array}{l}82,2 \\
17,8\end{array}$ \\
\hline $\begin{array}{l}\text { Lighting } \\
<60 \mathrm{Lux} \\
\geq 60 \mathrm{Lux}\end{array}$ & $\begin{array}{l}26 \\
19 \\
\end{array}$ & $\begin{array}{l}57,8 \\
42,2\end{array}$ & $\begin{array}{l}14 \\
31\end{array}$ & $\begin{array}{l}31,1 \\
68,9\end{array}$ \\
\hline $\begin{array}{l}\text { Floor type } \\
\text { Not waterproof } \\
\text { Waterproof }\end{array}$ & $\begin{array}{c}4 \\
41 \\
\end{array}$ & $\begin{array}{c}8,9 \\
91,1 \\
\end{array}$ & $\begin{array}{c}6 \\
39 \\
\end{array}$ & $\begin{array}{l}13,3 \\
86,7 \\
\end{array}$ \\
\hline $\begin{array}{l}\text { Cooking fuel } \\
\text { Not good } \\
\text { Good }\end{array}$ & $\begin{array}{c}5 \\
40 \\
\end{array}$ & $\begin{array}{l}11,1 \\
88,9 \\
\end{array}$ & $\begin{array}{c}2 \\
43 \\
\end{array}$ & $\begin{array}{r}4,4 \\
95,6 \\
\end{array}$ \\
\hline $\begin{array}{l}\text { Economic status } \\
\text { Poor } \\
\text { Not poor }\end{array}$ & $\begin{array}{l}24 \\
21 \\
\end{array}$ & $\begin{array}{l}53,3 \\
43,7 \\
\end{array}$ & $\begin{array}{l}18 \\
27 \\
\end{array}$ & $\begin{array}{l}40 \\
60 \\
\end{array}$ \\
\hline $\begin{array}{l}\text { Status of BCG Immunization } \\
\text { No } \\
\text { Yes }\end{array}$ & $\begin{array}{c}5 \\
40 \\
\end{array}$ & $\begin{array}{l}11,1 \\
88,9 \\
\end{array}$ & $\begin{array}{c}3 \\
42 \\
\end{array}$ & $\begin{array}{c}6,7 \\
93,3 \\
\end{array}$ \\
\hline $\begin{array}{l}\text { Cigarettes Exposure } \\
\text { Yes } \\
\text { No }\end{array}$ & $\begin{array}{c}42 \\
3 \\
\end{array}$ & $\begin{array}{c}93,3 \\
6,7 \\
\end{array}$ & $\begin{array}{l}34 \\
11 \\
\end{array}$ & $\begin{array}{l}75,6 \\
24,4 \\
\end{array}$ \\
\hline $\begin{array}{l}\text { Contact history } \\
\text { Yes } \\
\text { No }\end{array}$ & $\begin{array}{l}32 \\
13 \\
\end{array}$ & $\begin{array}{l}71,1 \\
28,9 \\
\end{array}$ & $\begin{array}{l}10 \\
35 \\
\end{array}$ & $\begin{array}{l}22,2 \\
77,8 \\
\end{array}$ \\
\hline $\begin{array}{l}\text { Knowledge } \\
\text { Less } \\
\text { Better }\end{array}$ & $\begin{array}{l}25 \\
20 \\
\end{array}$ & $\begin{array}{l}55,6 \\
44,4\end{array}$ & $\begin{array}{l}18 \\
27\end{array}$ & $\begin{array}{l}40 \\
60\end{array}$ \\
\hline $\begin{array}{l}\text { Attitude } \\
\text { Less } \\
\text { Better } \\
\end{array}$ & $\begin{array}{l}22 \\
23 \\
\end{array}$ & $\begin{array}{l}48,9 \\
51,1 \\
\end{array}$ & $\begin{array}{l}11 \\
34 \\
\end{array}$ & $\begin{array}{l}24,4 \\
75,6\end{array}$ \\
\hline
\end{tabular}

According to the data above, it shows that the group of cases which were sampled were 45 people. In this group of cases, there are amounted: age $\geq 5$ years as many as 30 people $(66.7 \%)$, male 35 people (77.8), higher education as many as 25 people (55.6\%), occupancy density that meets the requirements as many as 26 samples $(57.8 \%)$, the amount of ventilation that does not meet the requirements is 32 samples $(71.1 \%)$, house humidity that does not meet the requirements is 41 samples (91.1\%), MTB temperature as many as 33 samples (73.3\%), house lighting that does not meet the requirements as many as 26 samples (57.8\%), the type of waterproof floor as much as 41 samples (91.1\%), proper cooking fuel as many as 40 samples $(88.9 \%)$, poor economic status as many as 24 people (53.3\%), in BCG immunization as many as 40 samples $(88.9 \%)$, there were 42 samples of cigarette exposure (93.3\%), a contact history of 32 samples $(71.1 \%)$, a level of insufficient knowledge of 25 samples $(55.6 \%)$, good behavior as many as 23 samples $(51.1 \%)$. 
Table 3:-Bivariate Analysis Result

\begin{tabular}{|c|c|c|c|}
\hline Variables & p-value & OR & OR (CI 95\%) \\
\hline Occupancy Density & 0,514 & 1,5 & $(0,620-3,443)$ \\
\hline Luas Ventilasi & 0,011 & 3,4 & $(1,404-8,080)$ \\
\hline Home Humidity & 0,352 & 2,2 & $(0,616-7,970)$ \\
\hline House Temperature & 0,816 & 1,2 & $(0,498-3,097)$ \\
\hline Home Lighting & 0,020 & 3,0 & $(1,276-7,197)$ \\
\hline Floor type & 0,737 & 0,6 & $(0,166-2,419)$ \\
\hline Cooking fuel & 0,434 & 2,7 & $(0,493-14,644)$ \\
\hline Economic status & 0,291 & 1,7 & $(0,743-3,955)$ \\
\hline Status of BCG Immunization & 0,714 & 1,8 & $(0,392-0,7807)$ \\
\hline Cigarette Exposure & 0,042 & 4,5 & $(1,169-17,547)$ \\
\hline Contact History & 0,000 & 8,6 & $(3,320-22,358)$ \\
\hline Mother's knowledge & 0,205 & 1,9 & $(0,811-4,332)$ \\
\hline Mother's Behavior & 0,029 & 3,0 & $(1,206-7,247)$ \\
\hline
\end{tabular}

After conducting the univariate analysis, then followed by bivariate analysis with Chi Square test. This analysis aims to determine the correlation of each independent variable with the dependent variables. The statistical test results can be seen from the $\mathrm{p}$ value which will always be directly proportional to the $95 \%$ CI limit. If the value of $\mathrm{p}<0.05$, the $95 \%$ CI limit will not pass 1 , so that it is said to be significant or related and meaningful. If the value of $p>0.05$, the $95 \%$ CI limit will pass 1 , so that it is said to be insignificant or unrelated and meaningless. Based on the table above, the related variables were the area of ventilation, home lighting, cigarette exposure, contact history, behavior. Whereas the unrelated variables were occupancy density, home humidity, floor type, cooking fuel, economic status, BCG immunization status, knowledge and home temperature.

Table 4:-Candidate Variable for Multivariate Analysis

\begin{tabular}{|c|l|c|c|c|}
\hline No & \multicolumn{1}{|c|}{ Risk Factors } & $p$ & OR & $(95 \%)$ CI \\
\hline 1 & Ventilation Area & 0,011 & 3,4 & $(1,404-8,080)$ \\
\hline 2 & Home Lighting & 0,020 & 3,0 & $(1,276-7,197)$ \\
\hline 3 & Cigarette Exposure & 0,042 & 4,5 & $(1,169-17,547)$ \\
\hline 4 & Contact History & 0,000 & 8,6 & $(3,320-22,358)$ \\
\hline 5 & Knowledge & 0,205 & 1,9 & $(0,811-4,332)$ \\
\hline 6 & Behavior & 0,029 & 3,0 & $(1,206-7,247)$ \\
\hline
\end{tabular}

After conducting the bivariate analysis, then researcher was carried out multivariate analysis, in order to determine the most dominant variable. The variables that is analyzed in logistic regression were bivariate variables that had $\mathrm{p}$ $<0.25$.

Table 5:-Multivariate Analysis Results

\begin{tabular}{|l|c|c|c|c|}
\hline \multicolumn{1}{|c|}{ Risk Factors } & $\boldsymbol{p}$ & $\mathbf{E x p}(\mathbf{B})$ & $\mathbf{( 9 5 \% ) C I}$ & B \\
\hline Ventilation area & 0,003 & 5,360 & $1,760-16,321$ & 1,679 \\
\hline Contact History & 0,000 & 11,973 & $3,961-36,191$ & 2,483 \\
\hline Constant & & & & $-2,099$ \\
\hline
\end{tabular}

Based on the table above, the results of multivariate statistical analysis showed that there are 2 dominant risk factor for the incidence of Tuberculosis in children that appears. They are the contact history factor with $\mathrm{p}=0,000 \mathrm{OR}=11,9$ and ventilation area $\mathrm{p}=0,003, \mathrm{OR}=5,4$. The results of multivariate analysis can also produce regression equation models that can estimate the likelihood children can suffer from Tuberculosis in children. The results of the calculation of the probability formula, it can be concluded that children who have a history of contact and live in house with ineligible ventilation area have the possibility to suffer from Tuberculosis by $88,6 \%$.

\section{Discussion:-}

In this study, samples according to age in both the case group and the control group were mostly aged $\geq 5$ years old. Based on Central Statistical Agency data from Sumedang regency, the population aged 5-14 years as many as 188,803 people are more than the population aged <5 years which have as many as 96,072 people. According to gender, both the case group and the majority control group were male. From the BPS data of Sumedang Regency in 2018, ages $0-14$ years, male (145,661 people) were more than female (139,214 people). ${ }^{10}$ According to the education 
level of the mother, in the case group there were more low educated (elementary school-junior high school) of 44.4\% while in the control group there were more highly educated (High school-university graduates) of 48.9\%.Than there is a significant correlation between the extent of ventilation and the incidence of Tuberculosis in children in Sumedang Regency. The results of this study are in line with the results of Mudiyono's (2015) study which stated that ventilation was associated with the incidence of Tuberculosis in children. Houses that do not have good ventilation will increase the concentration of microorganisms. The risk for the occurrence of Tuberculosis in children in respondents with ventilation that does not meet the requirements 3.4 times greater than the respondents who have ventilation that meets the requirements. ${ }^{11}$ Adverse children life environmental conditions, as high humidity and poor ventilation can increase the risk of $\mathrm{TB} .{ }^{12}$

Based on this study there is a significant correlation between lighting and the incidence of Tuberculosis in children in Sumedang Regency. Lack of natural light that enters the house, especially sunlight, apart from being uncomfortable there is also a medium or a good place to live and develop of germs. Natural lighting that meets the requirements is able to kill pathogenic bacteria in the air such as Mycobacterium tuberculosis. ${ }^{13}$ Sun lighting has the power to kill bacteria, at least 60 lux. ${ }^{14}$ Than there was a significant correlation between exposure of cigarette smoke to Tuberculosis in children. The risk for the occurrence of Tuberculosis in children of respondents with cigarette' exposure is 4.5 times greater than that children who are not exposed to cigarette smoke. The results of this study are in line with the research of Sanjay (2013) which states that there is a significant correlation between exposure to cigarette smoke and the incidence of Tuberculosis in children $(\mathrm{p}=0.03){ }^{5}$. Data obtained that $34.4 \%$ of children in America, at least one adult smoker lives in one house. Children with active and passive smoking status have a greater tendency to be infected with Tuberculosis germs and experience respiratory infections. Smoking can harm and have an effect on the immune system, respiratory tract, pneumonia, and tuberculosis. ${ }^{15,16}$ Biological explanation that smoke increases the chances of obtaining TB, reduces the ability of phagocytosis alveolar macrophages and decreased immune response and/or CD4 + lymphopenia because nicotine in cigarettes has been given as a reason for increased susceptibility to pulmonary tuberculosis. ${ }^{17}$

Based on this study there was a significant correlation between the contact history with the incidence of Tuberculosis in children. Transmission of Tuberculosis in children is through the air with the general source of transmission adult Tuberculosis patients with Acid-Fast Bacillus (AFB) (+). ${ }^{6}$ Inside the patient's sputum with AcidFast Bacillus (AFB) (+) there are many Tuberculosis bacteria. When a Tuberculosis patient coughs and sneezes, he spreads around 3000 germs into the air in the form of sputum called droplet nuclei. This very small sprinkling of sputum hovers in the air and the people around it will be exposed to this infectious splash, including children. In order to hold down a weak child, children are very vulnerable to contracting Tuberculosis. ${ }^{18}$ The results of this study are also in line with the research results of Caleb Joseph Attah (2018) risk for the onset of child TB in respondents with a contact history with adult TB 2.9 times greater than respondents who have no history Contact with adult TB. ${ }^{19}$ The research results also in line with Sharma (2018) that there is a significant link between the child's contact history with TB BTA +2 and +3 sufferers with TB of children. ${ }^{20}$ Close contact with adult TB patients can be seen from 2 aspects that are aspects of distance such as using "one bed" criteria and the time aspect "time intensity $</>8$ hours/day. ${ }^{21}$ Than there was a significant relationship between the behavior of mothers and the incidence of Tuberculosis in children. The risk for the occurrence of Tuberculosis in children in the behavior of mothers who are less well 3 times greater than the behavior of a good mother. According to Hendrik L Bloom, the degree of public health are influenced by 4 factors, namely: environment, behavior, health services and descendant. Among the four factors according to the bloom of environmental and behavioral factors are the factors that most influencing the degree of public health. ${ }^{22}$

Based on this study there was no significant correlation between occupancy density and the incidence of Tuberculosis in children. In the field both the group of cases and the majority of control groups had residential occupancy densities that met the requirements $(\geq 9 \mathrm{~m} 2)$, such as in the case group at $57.8 \%$ and in the control group at $66.7 \%$. This is in line with the research of Rikha (2012) which mentions the population density of the respondent has no relation with pulmonary tuberculosis incidence. ${ }^{23}$ Mycobacterium tuberculosis grows at a temperature of $25^{\circ} \mathrm{C}-40^{0} \mathrm{C} .{ }^{14}$ Than the majority of respondents' homes were in the case group and in the control group, entering the range of TB bacteria growing temperatures, respectively $73.3 \%$ and $68.9 \%$. This is in line with the 2018 data which states the average temperature of Sumedang regency $26^{\circ} \mathrm{C}-29^{\circ} \mathrm{C}$. So that statistically with the chi square test there is no significant correlation $(\mathrm{p}=0.816)$ even though it means that the Regency of Sumedang has a high potential for Tuberculosis because it supports the temperature of growing TB bacteria. In this study, house humidity was measured and categorized into humidity to meet the requirements $(40 \%-70 \%)$ and humidity did not meet the 
requirements $(<40 \%$ and $>70 \%)$. Based on the results of this study indicate that the results of the chi square test $\mathrm{p}$ value $=0.352(>0.05)$ can be interpreted that there is no significant correlation between the humidity of the house and the incidence of Tuberculosis in children at Sumedang Regency. This is because the majority of houses, both case groups and controls, have house humidity that does not meet the requirements. In line with Meteorological, Climatological, And Geophysical Agency 2018 data which shows that the humidity of Sumedang $75 \%-83 \%$. ${ }^{10}$

In this study, the type of house floor was measured and categorized into waterproof floor if it is made of cement / pavement/ tile / ceramic and the floor is not waterproof if it is still in the form of soil. In the field, the floor of the house in both the case group and the majority of control group were waterproof with $91.1 \%$ and $86.7 \%$ so that the variable did not show a statistically significant influence on the incidence of Tuberculosis in children $(\mathrm{p}=0.737)$. The results of this study are in line with the results of research by Mudiyono (2015) which states that the type of floor is not related to the incidence of Tuberculosis in children with $\mathrm{p}$ value $=0.552$. $^{11}$ The results of this research in line with the research result of Zia Faizaty (2018) which mentions the floor type is not related to the incidence of TB children with $\mathrm{p}$ value $=1.000 .^{7}$ Than cooking fuel is categorized as a proper cooking fuel if it is from electricity and LPG. Meanwhile a non proper cooking fuel if it is from fuel wood / charcoal / briquettes / coconut shells. In the field, cooking fuel in both the case group and the majority control group was proper with $88.9 \%$ and $95.6 \%$, so that the variable did not show a statistically significant influence on the incidence of Tuberculosis in children $(\mathrm{p}=$ 0.434). So that it can be possible the incidence of Tuberculosis in children here because of other risk factors. The results of the study in India that the fuel cooking from wood is a risk factor pulmonary tuberculosis $(\mathrm{OR}=5.2){ }^{15}$

According to BPS 2018, poor economic status can be said if the expenditure per capita per month is below the poverty line which is Rp. 344,427 based on expenditure per capita of West Java province. ${ }^{10}$ According to the results of this study, it indicates that the value of $\mathrm{p}=0.291(>0.05)$ so that it can be interpreted that there is no significant correlation. The results of this study are in line with the results of Kamalina study (2015) which states that the socioeconomic level does not have any correlation with the incidence of Tuberculosis in children $(\mathrm{OR}=2.40, \mathrm{CI} 95 \%=$ 0.87-6.55). ${ }^{24}$ Than, the group of cases that were not immunized by BCG were $11.1 \%$ while the control group that were not immunized by BCG was $6.7 \%$. So the majority of both case groups and controls have received BCG immunization. The results of the chi square test in this study showed $p=0.714(>0.05)$ which means there was no significant correlation between the contact history with Tuberculosis in children. The results of this study are in line with the results of the Kamalina study (2015) which stated that the BCG immunization history did not have any association with the incidence of Tuberculosis in children $(\mathrm{OR}=2.25, \mathrm{CI} 95 \%=0.61-8.18){ }^{24}$ From the results of this study, the proportion of lower mom's knowledge in the case group was $55.6 \%$ higher than the proportion of knowledge of mothers who were less in the control group 40\%. However, statistically the chi square test shows $\mathrm{p}=$ 0.205 (>0.05 OR 1.9) which means there is no significant correlation between knowledge and Tuberculosis in children. The results of this study are in line with the results of Mudioyono's research (2015) which states that the level of knowledge is not related to the incidence of Tuberculosis in children. ${ }^{11}$

\section{Conclusion:-}

The results of bivariate analysis with Chi Square test aims to determine the correlation of each risk factor with the incidence of Tuberculosis in children: the related variables were ventilation area $(\mathrm{p}=0.011, \mathrm{OR}=3.4)$ home lighting $(\mathrm{p}=0.020, \mathrm{OR}=3.0)$, cigarette exposure $(\mathrm{p}=0.042, \mathrm{OR}=4.5)$, contact history $(\mathrm{p}=0,000 \mathrm{OR}=8.6)$, behavior $(\mathrm{p}=0.029, \mathrm{OR}=3.0)$. The unrelated variables were occupancy density $(\mathrm{p}=0.514)$, house humidity $(\mathrm{p}=$ 0.352), type of floor ( $p=0.737)$, cooking fuel $(\mathrm{p}=0.434)$, economic status $(\mathrm{p}=0.291)$, BCG immunization status $(\mathrm{p}=0.714)$, knowledge $(\mathrm{p}=0.205)$ and home temperature $(\mathrm{p}=0.816)$. The results of multivariate analysis with logistic regression test aims to find out the dominant factor such as contact history factor with $\mathrm{p}=0,000 \mathrm{OR}=11,9$ and ventilation area $\mathrm{p}=0,003, \mathrm{OR}=5,4$. 


\section{References:-}

1. Kementerian Kesehatan Republik Indoensia. Infodatin Kemeneterian Kesehatan R.I 2017. Jakarta; 2017.

2. WHO. Tuberculosis Report. 2018.

3. Hastuti P, Widiastuti A. Pengetahuan dan sikap ibu balita tentang TB paru. 2018;14(1):7-13.

4. Kementerian Kesehatan Republik Indonesia. Profil Kesehatan Indonesia. Jakarta; 2017. 496 p.

5. Jain SK, Ordonez A, Kinikar A, Gupte N, Thakar M, Mave V, et al. Pediatric Tuberculosis in Young Children in India: A Prospective Study. 2013;2013.

6. Nastiti R, Nawas A, Setyanto DB, Kaswandani N, Triasih R, Indawati W, et al. Buku petunjuk teknis manajemen dan tatalaksana TB anak (National guideline on the management of tuberculosis in children). Ministry of Health of the Republic of Indonesia. Jakarta; 2016. p. 112.

7. Zuraida ZF, Pramatama S, Wijayanti M. Risk factors associated with childhood tuberculosis : a case control study in endemic tuberculosis area. 2018;5(11):4702-6.

8. Sastroasmoro S. Dasar-dasar metodologi penelitian klinis. 5th ed. Jakarta; 2014. 522 p.

9. Murti B. Prinsip dan Metode Riset Epidemiologi. 4th ed. Surakarta; 2016. 606 p.

10. Sumedang B. Kabupaten Sumedang Dalam Angka. Badan Pusat Statistik Kabupaten Sumedang, editor. Kabupaten Sumedang: BPS Kabupaten Sumedang; 2018.

11. Mudiyono, Wahyuningsih N, Adi S. Hubungan antara perilaku dan lingkungan fisik rumah dengan kejadian tuberkulosis di Kota Pekalongan. J Kesehat Lingkung Indones. 2015;14:45-50.

12. Lestari P, Sustini F, Endaryanto A, Asih R. Home humidity increased risk of tuberculosis in children living with adult active tuberculosis cases. 2011;30(3).

13. Hernawan AD, Khitama I. Analisis spasial sebaran kasus dan lingkungan berpotensi penularan tuberkulosis paru. 2014;1-8.

14. Ruswanto B, Raharjo M. Analisis Spasial Sebaran Kasus Tuberkulosis Paru Ditinjau Dari Faktor Lingkungan Dalam dan Luar Rumah di Kabupaten Pekalongan. 2012;11(1):22-8.

15. Halim, Naninh R, Dwi Budi Satrio. Faktor Risiko Kejadian TB Paru Pada Anak usia 1-5 Tahun di Kabupaten Kebumen. 2015;17.

16. Nurjana MA, Kesehatan BL, Labuan K, Donggala K. Faktor Risiko Terjadinya Tuberkulois Paru Usia Produktif ( 15-49 Tahun) Di Indonesia. 2015;163-70.

17. Narasimhan P, Wood J, Macintyre CR, Mathai D. Risk Factors for Tuberculosis. 2013;2013.

18. Ditjen P2PL Kementerian Kesehatan RI, editor. Pedoman Nasional Pengendalian Tuberkulosis. Jakarta: Ditjen P2PL Kementerian Kesehatan RI; 2014. 1-27 p.

19. Joseph C, Oguche S, Egah D, Nandi T, Banwat M, Godwin A. Risk factors associated with paediatric tuberculosis in an endemic setting. Alexandria J Med [Internet]. 2018;54(4):403-9. Available from: https://doi.org/10.1016/j.ajme.2018.05.002

20. Sharma KR, Bhatta NK, Niraula SR. A Measure of Transmission of Tuberculosis Infection among Children in Household Contact. 2018;(1).

21. Febrian MA. Faktor-faktor yang berhubungan dengan kejadian TB paru anak di wilayaj puskesmas Garuda Kota Bandung. 2015;III(2):64-79.

22. Wulandari AA, Adi MS. Faktor risiko dan potensi penularan tuberkulosis paru di Kabupaten Kendal, Jawa Tengah. 2015;14(1):7-13.

23. Lingkungan S, Kejadian D, Di T. Rikha Nurul Pertiwi Alumnus Fakultas Kesehatan Masyarakat UNDIP () 2012. 2012;1(1).

24. Yustikarini K, Sidhartani M. Faktor risiko sakit tuberkulosis pada anak yang terinfeksi. J Sari Pediatr. 2015;17(16):136-40. 